\title{
Biosynthesis, Characterization, and Antidermatophytic Activity of Silver Nanoparticles Using Raamphal Plant (Annona reticulata) Aqueous Leaves Extract
}

\author{
P. Shivakumar Singh and G. M. Vidyasagar \\ Medicinal Plants and Microbiology Research Laboratory, Department of Post Graduate Studies and Research in Botany, \\ Gulbarga University, Gulbarga, Karnataka 585 106, India
}

Correspondence should be addressed to G. M. Vidyasagar; gmvidyasagar@rediffmail.com

Received 21 December 2013; Accepted 3 February 2014; Published 8 April 2014

Academic Editors: R. Kalyanaraman and P. Supiot

Copyright (c) 2014 P. Shivakumar Singh and G. M. Vidyasagar. This is an open access article distributed under the Creative Commons Attribution License, which permits unrestricted use, distribution, and reproduction in any medium, provided the original work is properly cited.

\begin{abstract}
The present work investigated the biosynthesis of silver nanoparticles using Annona reticulata leaf aqueous extract. The biosynthesised silver nanoparticles were confirmed by visual observation and UV-Vis spectroscopy. Appearance of dark brown colour indicated the synthesis of silver in the reaction mixture. The silver nanoparticles were found to be spherical, rod, and triangular in shape with variable size ranging from 23.84 to $50.54 \mathrm{~nm}$, as evident by X-ray diffraction studies, TEM. The X-ray diffraction studies, energy dispersive X-ray analysis, and TEM analysis indicate that the particles are crystalline in nature. The nanoparticles appeared to be associated with some chemical compounds which possess hydroxyl and carbonyl groups, confirmed by FTIR. This is the first and novel report of silver nanoparticles synthesised from Annona reticulata leaves extract and their antidermatophytic activity.
\end{abstract}

\section{Introduction}

The field of nanotechnology is one of the most active areas of research in modern materials science and technology. It provides the ability to create materials, devices, and systems with fundamentally new functions and properties [1]. Recently, research in synthesis of nanoparticles using microbes and plant extracts gained more importance due to its ecofriendliness; flexible and main point is the evasion of toxic chemicals [2]. When compared to microbes, plant mediated synthesis is actively being practiced by the researchers for its positive advantages like avoidance of maintaining the microbial culture, being time-consuming, and being cost effective [3]. Previously, various plants have been successfully used for the synthesis of biogenic metal nanoparticles [4]. Nanoparticles are synthesized using plant materials such as, Mucuna pruriens [5], Cassia occidentalis [6], banana peel [7], Azadirachta indica [8], Aloe vera [9], Emblica officinalis [10], Capsicum annuum [11], Cinnamomum camphora [12],
Gliricidia sepium Jacq. [13], Carica papaya [14], Opuntia ficusindica [15], Murraya koenigii [16], Ocimum sanctum [17], and Saururus chinensis [18]. The various phytochemicals present within the plant result in effective reduction of silver salts to nanoparticles but their chemical framework is also effective at wrapping around the nanoparticles to provide excellent robustness against agglomeration [19]; the synthesised silver nanoparticles were used effectively against multidrug resistant bacteria [20]; it can be used in many antimicrobial preparations [21]; Durán et al. [22] successfully developed silver nanoparticle impregnated wound dressings and textile fabrics which can be used for burnt patients. Silver nanoparticles are also used for the preparation of surgical masks [23]. Annona reticulata is a semievergreen plant belonging to the family Annonaceae. A. reticulata commonly known as raamphal plant or bullock's heart is widely distributed all over India. The leaves have been using in the treatment of insecticides, helmintic, styptic epilepsy, toothache, tumor, fever, dysentery and are also used externally as suppurant. The bark is used in 
treating antidysenteric and vermifuge. The root, bark, leaves, and stem of this plant possess isoquinoline alkaloids [24], whereas still there was no reports on biosynthesis of AgNPs (silver nanoparticles) using leaves of raamphal plant.

In the present study, A. reticulata leaf aqueous extract was used for the synthesis of silver nanoparticles and their antidermatophytic activity was evaluated.

\section{Materials and Methods}

2.1. Collection of Material. Fresh leaves of Annona reticulate were collected from botanical garden of Gulbarga University campus. Silver nitrate $\left(\mathrm{AgNO}_{3}\right)$ is procured from High Media Laboratories. Solutions were prepared with triply distilled water.

2.2. Preparation of the Extract. $25 \mathrm{~g}$ of A. reticulata fresh leaves was weighed, thoroughly washed in distilled water, cut into fine pieces, and smashed into $100 \mathrm{~mL}$ sterile distilled water and plant extract was boiled for 5 to $6 \mathrm{~min}$ and filtered through Whatman No. 1 filter paper (pore size $0.45 \mu \mathrm{m}$ ) and was further filtered through $0.22 \mu \mathrm{m}$ sized filters. The extract was stored at $4^{\circ} \mathrm{C}$ for further experiments.

2.3. Synthesis of Silver Nanoparticles from Annona reticulata Leaf Extract. The aqueous solution of $1 \mathrm{mM}$ silver nitrate $\left(\mathrm{AgNO}_{3}\right)$ was prepared and used for the synthesis of silver nanoparticles. $1 \mathrm{~mL}$ of $A$. reticulata leaf extract was added into $100 \mathrm{~mL}$ of $1 \mathrm{mM}$ silver nitrate aqueous solution for reduction into $\mathrm{Ag}^{+}$ions and kept for incubation for $20 \mathrm{~min}$ at room temperature.

2.4. Characterization. The synthesized AgNPs were characterized using UV-vis Elico double spectrophotometer operated at with $1 \mathrm{~nm}$ resolution with optical length of $10 \mathrm{~mm}$. UVvis analysis of the reaction mixture was observed for a period of $300 \mathrm{~s}$. For the study of crystallinity, films of colloidal AgNPs formed on $\mathrm{Si}(\mathrm{III})$ substrates by drop coating were used for $\mathrm{X}$-ray-diffraction (XRD) study. The data was obtained using Ricago X-Ray Diffractometer (Japan), operated at $30 \mathrm{kV}$ and $20 \mathrm{~mA}$ current with $\mathrm{Cu} \mathrm{Ka}(I=1.54 \AA)$. The transmission electron microscopy (TEM) images were obtained using Technai-20 Philips instrument operated at $190 \mathrm{keV}$. Biosynthesized silver nanoparticles solution drops on carbon coated copper grids were kept for $5 \mathrm{~min}$; the extra solution was removed using blotting paper. The film of TEM grid is exposed to IR light for drying. The powder sample of AgNPs was prepared by centrifuging the synthesized AgNPs solution at $10,000 \mathrm{rpm}$ for $20 \mathrm{~min}$. The solid residue was washed with deionized water to remove any unattached biological moieties to the surface of the nanoparticles, which are not responsible for biofunctionalization and capping. The resultant residue is then dried completely and the powder obtained was used for FTIR analysis carried out on a Nicolet iS5 FTIR with diamond ATR.

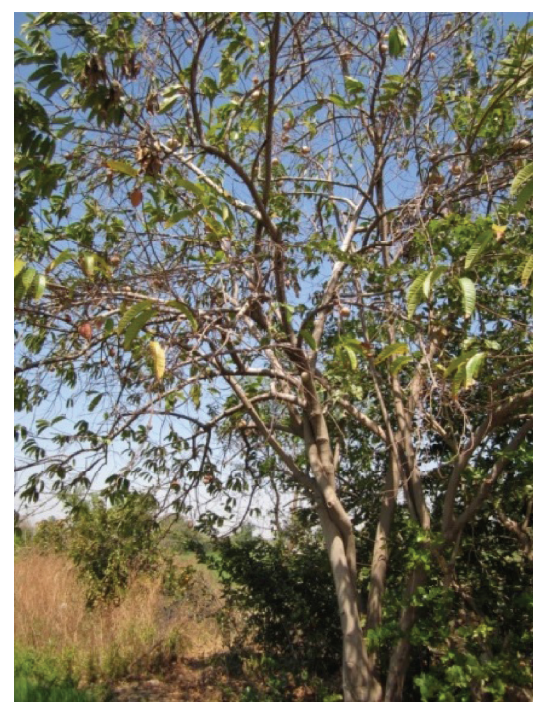

FIGURE 1: Annona reticulata leaves used for the synthesis of AgNPs.

\subsection{Antidermatophytic Activity of AgNPs Synthesised from A. reticulata Leaves Aqueous Extract}

2.5.1. Test Microorganisms. Three fungi Trichophyton rubrum, Trichophyton tonsurans, and Microsporum gypseum and three bacterial strains Staphylococcus aureus, Escherichia coli, and Bacillus subtilis were used in the present study; all the tested strains were obtained from M.R.M.C. Medical College, Gulbarga, Karnataka, India. These testcultures were grown in SDB, nutrient broth (Himedia, M002), at $37^{\circ} \mathrm{C}$ and maintained on nutrient and potato agar slants at $4^{\circ} \mathrm{C}$.

2.5.2. Agar-Well Diffusion Method [25]. The assay was conducted by agar-well diffusion method. About 15 to $20 \mathrm{~mL}$ of potato dextrose agar medium was poured in the sterilized petri dishes and allowed to solidify. The fungal strains were suspended in a saline solution $(0.85 \% \mathrm{NaCl})$ and adjusted to a turbidity of $0.5 \mathrm{McF}$ arland standards $(108 \mathrm{CFU} / \mathrm{mL}) .1 \mathrm{~mL}$ of fungal strains was spread over the medium using a sterilized glass spreader. Using flamed sterile borer, wells of $4 \mathrm{~mm}$ diameter were punctured in the culture medium. Required concentrations $(80,40,20$, and $10 \mu \mathrm{L} /$ well) were added to the wells. The plates thus prepared were left for diffusion of extracts into media for one hour in the refrigerator and then incubated at $37^{\circ} \mathrm{C}$. After incubation for $48 \mathrm{~h}$, the plates were observed for zones of inhibition. The diameter zone of inhibition was measured and expressed in millimetres. $1 \mathrm{mM} \mathrm{AgNo}_{3}$ solution and aqueous plant extract were used as negative control. Ketoconazole, streptomycin were used as positive control against fungi and bacteria $(1000 \mu \mathrm{g} / \mathrm{mL}$ conc. $40 \mu \mathrm{L} /$ well). The experiments were conducted in triplicate. The same method was followed for testing antibacterial activity using nutrient agar medium incubated at $37^{\circ} \mathrm{C}$ for $18 \mathrm{~h}$.

\section{Results and Discussion}

The biosynthesis of AgNPs using A. reticulata (Figure 1) fresh leaf aqueous extract (light yellowish) was carried out 
TABle 1: Antidermatophytic activity of AgNPs synthesised from aqueous leaf extract of Annona reticulata.

\begin{tabular}{|c|c|c|c|c|c|c|c|}
\hline \multirow{2}{*}{$\begin{array}{l}\text { Dermatophytic fungi } \\
\text { and bacterial strains }\end{array}$} & \multicolumn{7}{|c|}{ Zone of inhibition in $\mathrm{mm}$ at different conc. of Ag NPs } \\
\hline & $80 \mu \mathrm{L} /$ well & $60 \mu \mathrm{L} /$ well & $40 \mu \mathrm{L} /$ well & $20 \mu \mathrm{L} /$ well & $\begin{array}{c}\text { Leaf aqueous } \\
\text { extract }\end{array}$ & $\begin{array}{c}1 \mathrm{mM} \\
\mathrm{AgNo}_{3} \\
\text { solution }\end{array}$ & $\begin{array}{c}\text { Standard K \& S } \\
(1000 \mu \mathrm{g} / \mathrm{mL} \text { conc. })\end{array}$ \\
\hline T. rubrum & 13.00 & 10.00 & 07.00 & 05.00 & - & - & 22.00 \\
\hline T. tonsurans & 11.00 & 09.00 & 06.00 & 05.00 & - & - & 23.00 \\
\hline M. gypseum & 14.00 & 12.00 & 07.00 & 05.00 & - & - & 20.00 \\
\hline S. aureus & 20.00 & 17.00 & 13.00 & 09.00 & - & - & 32.00 \\
\hline B. subtilis & 18.00 & 14.00 & 11.00 & 07.00 & - & - & 35.00 \\
\hline E. coli & 22.00 & 20.00 & 16.00 & 11.00 & - & - & 30.00 \\
\hline
\end{tabular}

T. rubrum: Trichophyton rubrum, T. tonsurans: Trichophyton tonsurans, M. gypseum: Microsporum gypseum, S. aureus: Staphylococcus aureus, B. subtilis: Bacillus subtilis, E. coli: Escherichia coli. Standards K: ketoconazole against fungi, S: streptomycin against bacteria.

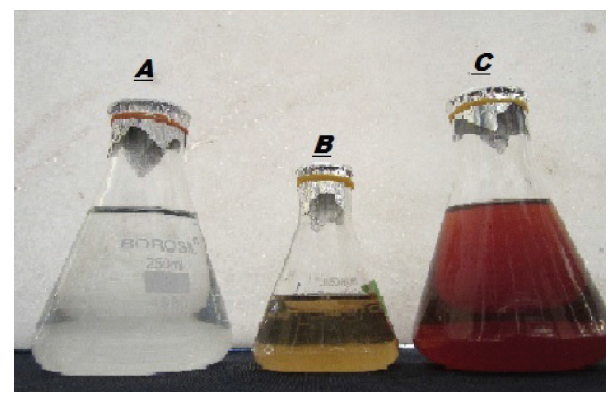

FIGURE 2: Synthesis of silver nanoparticles using Annona reticulata aqueous leaves extract treating with $\mathrm{AgNO}_{3}$ solution at room temperature. (A) Silver nitrate $\left(\mathrm{AgNO}_{3}\right)$ solution; (B) A. reticulata aqueous leaf extract; (C) after formation AgNPs change the colour of $\mathrm{AgNO}_{3}$ solution.

and reported in the present work. $2.5 \mathrm{~mL}$ of $A$. reticulata leaf aqueous extract was added to $250 \mathrm{~mL}$ of $1 \mathrm{mM} \mathrm{AgNO}_{3}$ solution. The colour of the reaction mixture after 20 minutes at room temperature changes from transparent to dark brown colour; this observation is strong sign for the formation of AgNPs (Figure 2). The formation and stability of the reduced AgNPs in the colloidal solution was examined by using UV-vis spectral analysis. The UV-vis spectrum recorded from reaction mixture was plotted (Figure 3 ). The synthesized AgNPs were evaluated through Elico double beam spectrophotometer at a wavelength range of $400-500 \mathrm{~nm}$; a characteristic peak at $420 \mathrm{~nm}$ showed that the typical optical spectra for silver nanoparticles was $350 \mathrm{~nm}-550 \mathrm{~nm}$ in visible light region [26], confirming the formation of silver nanoparticles. The similar type of the silver nanoparticles peaks were reported in Geranium leaf [27]. The present wave length reports of $\mathrm{nm}$ were supported by the previous reports at similar $\mathrm{nm}[28,29]$.

The XRD pattern of AgNPs suggests that the particles are crystalline in nature. The intense diffraction peaks due to AgNPs are clearly observed at (111), (220) and (311), (380). All the peaks match well with the standard JCPDS file 04-0783 of silver shown in Figure 4.

TEM procedure was employed to visualize the size and shape of AgNPs formed. A typical TEM image of biologically

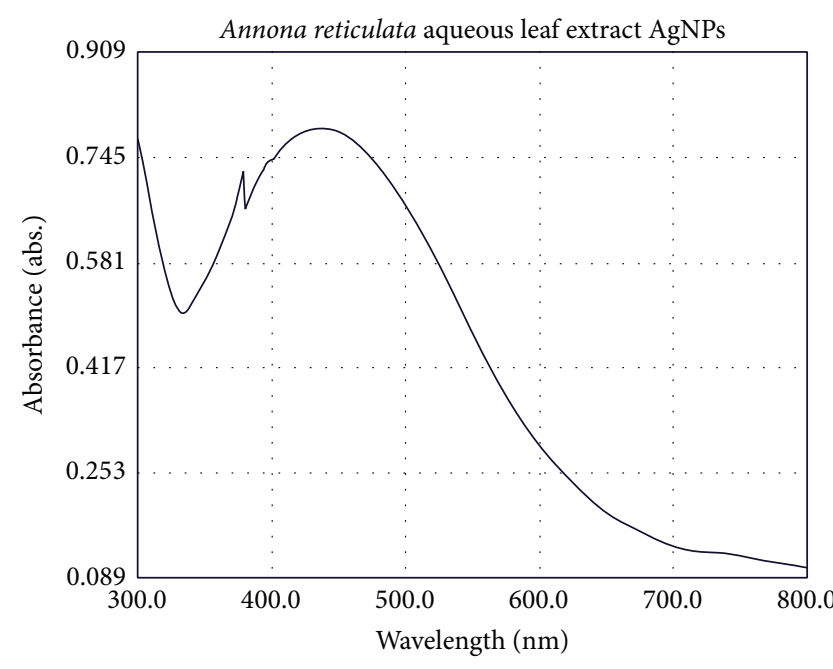

FIGURE 3: UV-vis spectrum of biofunctionalized AgNPs showing surface plasmon peak at $440 \mathrm{~nm}$.

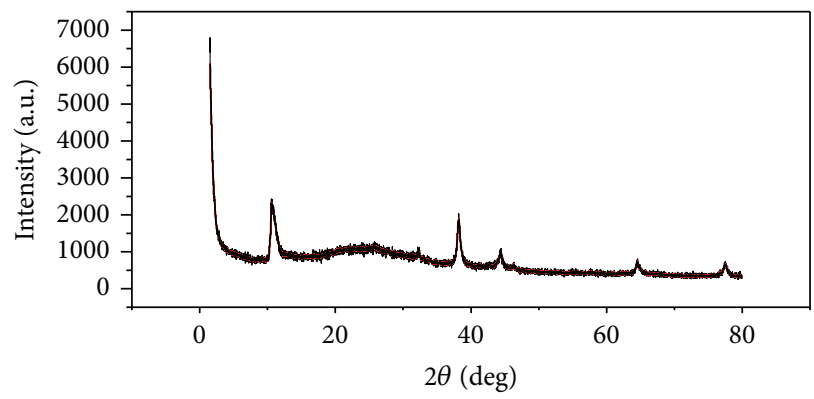

FIGURE 4: XRD patterns of biofunctionalized AgNPs.

synthesized AgNPs suggests that the particles are uneven in shape. Some are spherical, rod, and triangular shaped particles with a varying size of $23.84-50.54 \mathrm{~nm}$ shown in Figures 5(a) and 5(b). The FTIR measurement was carried out to identify the possible biomolecules in A. reticulata leaf extract responsible for capping leading to efficient stabilization of the AgNPs (Figure 6). The FTIR spectrum of silver nanoparticles manifests prominent absorption band located 

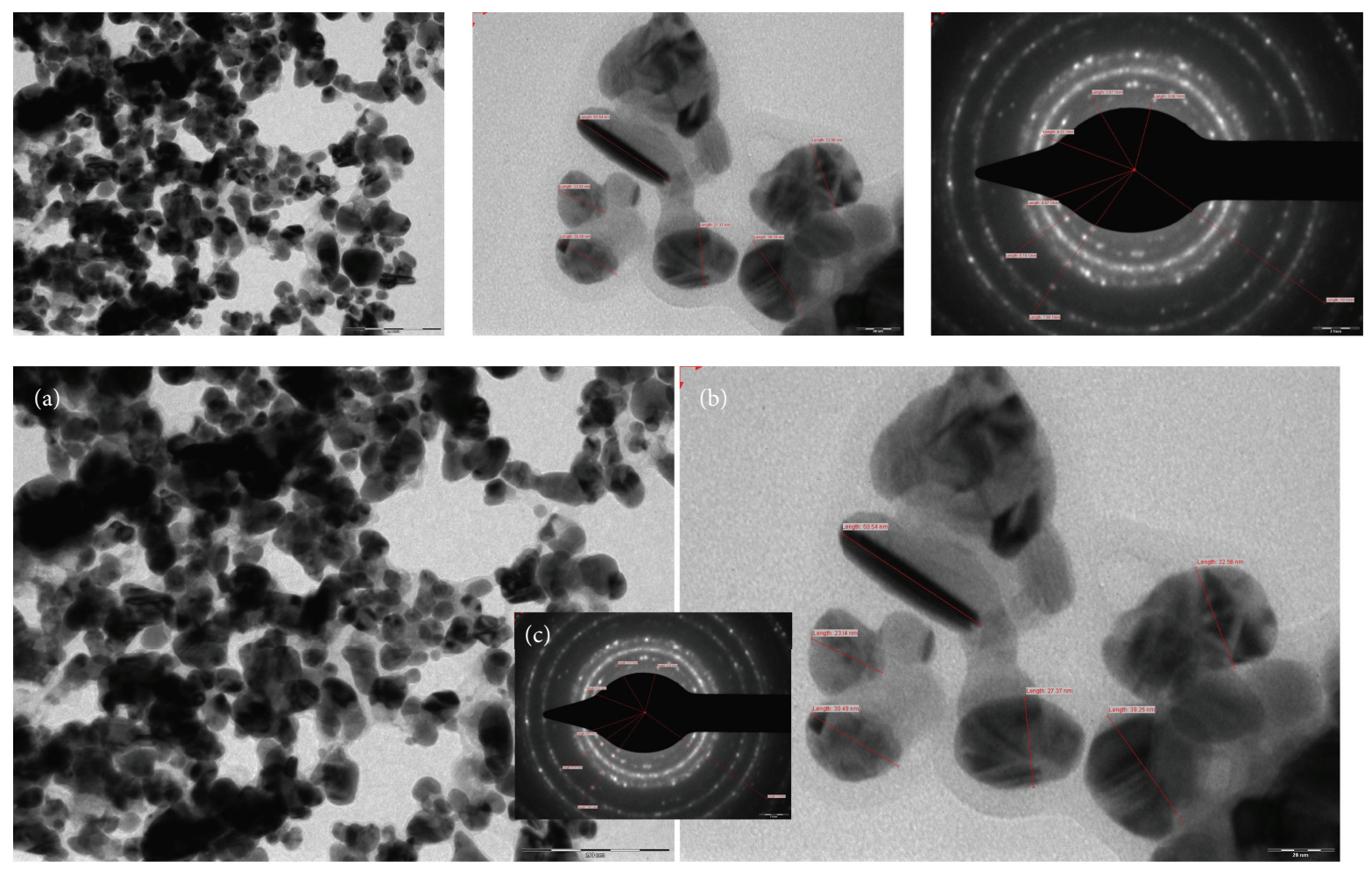

FIgURE 5: (a) and (b) TEM image of biofunctionalized AgNPs, (c) SAED pattern.

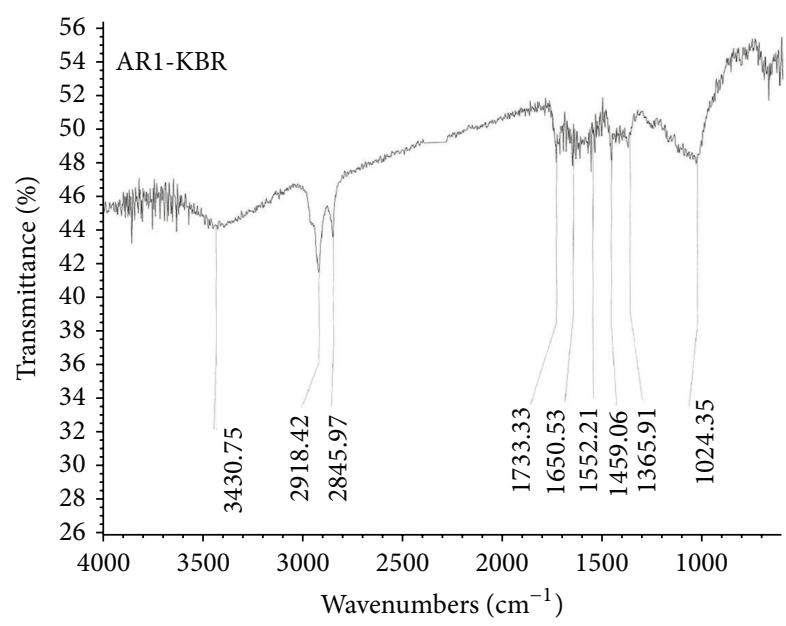

FigURE 6: FTIR spectrum of biofunctionalized AgNPs.

at 1650,53 and 1459,06 . The strong band at $1650 \mathrm{~cm}^{-1}$ may result from the $\mathrm{N}-\mathrm{H}$ stretching vibration and can be assigned as absorption bands of $\mathrm{C}=\mathrm{H},-\mathrm{O}-\mathrm{H},-\mathrm{S}-\mathrm{H},-\mathrm{N}=\mathrm{C}=\mathrm{N},-\mathrm{C}=\mathrm{O}$, and $-\mathrm{S}=\mathrm{O}$ stretching vibration. These are derived from water soluble compounds such as flavonoids, alkaloids, and polyphenols present in leaves. Biological components are known to interact with metal salts via these functional groups and mediate their reduction to nanoparticles [30].

The AgNPs of $A$. reticulata leaves at $80 \mu \mathrm{L} /$ well showed maximum antifungal activity against $M$. gypseum $14.00 \mathrm{~mm}$ followed by T. rubrum $13.00 \mathrm{~mm}$ and the least $11.00 \mathrm{~mm}$ zone of inhibition showed by $T$. tonsurans. Similarly, against bacteria the maximum activity of $22.00 \mathrm{~mm}$ was recorded against E. coli followed by $S$. aureus $20.00 \mathrm{~mm}$ and $B$. subtilis $18.00 \mathrm{~mm}$. The antidermatophytic activity was directly proportional to the concentration of AgNPs. Two negative controls, that is, plant aqueous extract and $\mathrm{AgNO}_{3}$ solutions, did not show activity against tested strains. Streptomycin sulphate and ketoconazole showed the inhibition zones $23.00 \mathrm{~mm}$ and $35.00 \mathrm{~mm}$, respectively (Table 1 ).

\section{Conclusion}

Biosynthesis of silver nanoparticles from A. reticulate leaf was shown to be stable and produce particles of crystallographic rod and irregular shapes. The synthesis procedure is ecofriendly in nature. The synthesized particles showed antidermatophytic activity, suggesting that they are useful as antimycotic agent.

\section{Conflict of Interests}

The authors declare that there is no conflict of interests regarding the publication of this paper.

\section{Acknowledgments}

The authors are pleased to thank IIT Mumbai for TEM analysis, USIC Gulbarga University for FTIR analysis, Department of Physics, Gulbarga University, Gulbarga, for XRD analysis, and Gulbarga University for providing facilities. 


\section{References}

[1] M. Karkare, Nanotechnology Fundamentals and Applications, IK International Publication, 2008.

[2] S. Mann, "Molecular tectonics in biomineralization and biomimetic materials chemistry," Nature, vol. 365, no. 6446, pp. 499-505, 1993.

[3] M. D. A. Farooqui, P. S. Chauhan, P. Krishnamoorthy, and J. Shaik, "Extraction of silver nanoparticles from the leaf extracts of Clerodendrum Inerme," Digest Journal of Nanomaterials and Biostructures, vol. 5, no. 1, pp. 43-49, 2010.

[4] C. Singh, V. Sharma, P. K. Naik, V. Khandelwal, and H. Singh, "A green biogenic approach for synthesis of gold and silver nanoparticles using zingiber officinale," Digest Journal of Nanomaterials and Biostructures, vol. 6, no. 2, pp. 535-542, 2011.

[5] S. Arulkumar and M. Sabesan, "Biosynthesis and characterization of gold nanoparticle using antiparkinsonian drug Mucuna pruriens plant extract," International Journal of Research in Pharmaceutical Sciences, vol. 1, no. 4, pp. 417-420, 2010.

[6] V. Arya, S. Yadav, S. Kumar, and J. P. Yadav, "Antimicrobial activity of Cassia occidentalis L, (leaf) against various human pathogenic microbes," Life Sciences and Medicine Research, vol. 9, pp. 1-11, 2010.

[7] A. Bankar, B. Joshi, A. Ravi Kumar, and S. Zinjarde, "Banana peel extract mediated synthesis of gold nanoparticles," Colloids and Surfaces B: Biointerfaces, vol. 80, no. 1, pp. 45-50, 2010.

[8] S. S. Shankar, A. Rai, A. Ahmad, and M. Sastry, "Rapid synthesis of $\mathrm{Au}, \mathrm{Ag}$, and bimetallic Au core-Ag shell nanoparticles using Neem (Azadirachta indica) leaf broth," Journal of Colloid and Interface Science, vol. 275, no. 2, pp. 496-502, 2004.

[9] S. P. Chandran, M. Chaudhary, R. Pasricha, A. Ahmad, and M. Sastry, "Synthesis of gold nanotriangles and silver nanoparticles using Aloe vera plant extract," Biotechnology Progress, vol. 22, no. 2, pp. 577-583, 2006.

[10] B. Ankamwar, C. Damle, A. Ahmad, and M. Sastry, "Biosynthesis of gold and silver nanoparticles using Emblica Officinalis fruit extract, their phase transfer and transmetallation in an organic solution," Journal of Nanoscience and Nanotechnology, vol. 5, no. 10, pp. 1665-1671, 2005.

[11] S. Li, Y. Shen, A. Xie et al., "Green synthesis of silver nanoparticles using Capsicum annuum L. extract," Green Chemistry, vol. 9, no. 8, pp. 852-858, 2007.

[12] J. Huang, Q. Li, D. Sun et al., "Biosynthesis of silver and gold nanoparticles by novel sundried Cinnamomum camphora leaf," Nanotechnology, vol. 18, no. 10, Article ID 105104, 2007.

[13] W. Raut Rajesh, R. Lakkakula Jaya, S. Kolekar Niranjan, D. Mendhulkar Vijay, and B. Kashid Sahebrao, "Phytosynthesis of silver nanoparticle using Gliricidia sepium(Jacq.)," Current Nanoscience, vol. 5, no. 1, pp. 117-122, 2009.

[14] N. Mude, A. Ingle, A. Gade, and M. Rai, "Synthesis of silver nanoparticles using callus extract of Carica papaya-a first report," Journal of Plant Biochemistry and Biotechnology, vol. 18, no. 1, pp. 83-86, 2009.

[15] A. Gade, S. Gaikwad, V. Tiwari, A. Yadav, A. Ingle, and M. Rai, "Biofabrication of silver nanoparticles by Opuntia ficusindica: in vitro antibacterial activity and study of the mechanism involved in the synthesis," Current Nanoscience, vol. 6, no. 4, pp. 370-375, 2010.

[16] S. R. Bonde, D. P. Rathod, A. P. Ingle, R. B. Ade, A. K. Gade, and M. K. Rai, "First report of Murraya koenigii mediated synthesis of silver nanoparticles and its activity against three human pathogenic bacteria," Nanoscience Methods, vol. 1, pp. 25-36, 2012.

[17] K. Mallikarjuna, G. Narasimha, G. R. Dillip et al., "Green synthesis of silver nanoparticles using Ocimum leaf extract and their characterization," Digest Journal of Nanomaterials and Biostructures, vol. 6, no. 1, pp. 181-186, 2011.

[18] P. C. Nagajyoti, T. N. V. K. V. Prasad, T. V. M. Sreekanth, and K. D. Lee, "Bio-fabrication of silver nanoparticles using leaf extract of Saururus chinenis," Digest Journal of Nanomaterials and Biostructures, vol. 6, no. 1, pp. 121-133, 2011.

[19] N. Ahmad, S. Sharma, M. K. Alam et al., "Rapid synthesis of silver nanoparticles using dried medicinal plant of basil," Colloids and Surfaces B: Biointerfaces, vol. 81, no. 1, pp. 81-86, 2010.

[20] A. Ingle, A. Gade, S. Pierrat, C. Sönnichsen, and M. Rai, "Mycosynthesis of silver nanoparticles using the fungus Fusarium acuminatum and its activity against some human pathogenic bacteria," Current Nanoscience, vol. 4, no. 2, pp. 141144, 2008.

[21] A. K. Gade, P. Bonde, A. P. Ingle, P. D. Marcato, N. Durán, and M. K. Rai, "Exploitation of Aspergillus niger for synthesis of silver nanoparticles," Journal of Biobased Materials and Bioenergy, vol. 2, no. 3, pp. 243-247, 2008.

[22] N. Durán, P. D. Marcato, G. I. H. De Souza, O. L. Alves, and E. Esposito, "Antibacterial effect of silver nanoparticles produced by fungal process on textile fabrics and their effluent treatment," Journal of Biomedical Nanotechnology, vol. 3, no. 2, pp. 203-208, 2007.

[23] Y. Li, P. Leung, L. Yao, Q. W. Song, and E. Newton, "Antimicrobial effect of surgical masks coated with nanoparticles," Journal of Hospital Infection, vol. 62, no. 1, pp. 58-63, 2006.

[24] K. M. Nadkarni, Indian Materia Medica, Popular Prakashan, Mumbai, India, 2002.

[25] S. Magaldi, S. Mata-Essayag, C. Hartung De Capriles et al., "Well diffusion for antifungal susceptibility testing," International Journal of Infectious Diseases, vol. 8, no. 1, pp. 39-45, 2004.

[26] A. Sileikaite, I. Prosycevas, J. Puiso, A. Juraitis, and A. Guobiene, "Analysis of silver nanoparticles produced by chemical reduction of silver salt solution," Materials Science (Medziagotyra), vol. 12, no. 4, pp. 287-291, 2006.

[27] S. S. Shankar, A. Ahmad, and M. Sastry, "Geranium leaf assisted biosynthesis of silver nanoparticles," Biotechnology Progress, vol. 19, no. 6, pp. 1627-1631, 2003.

[28] S. Basavaraja, S. D. Balaji, A. Lagashetty, A. H. Rajasab, and A. Venkataraman, "Extracellular biosynthesis of silver nanoparticles using the fungus Fusarium semitectum," Materials Research Bulletin, vol. 43, no. 5, pp. 1164-1170, 2008.

[29] R. Bhat, S. Ganachari, R. Deshpande, G. Ravindra, and A. Venkatraman, "Rapid biosynthesis of silver nanoparticles using areca nut (areca catechu) extract under microwave-assistance," Journal of Cluster Science, vol. 24, pp. 107-114, 2013.

[30] M. M. Ganesh Babu and P. Gunasekaran, "Production and structural characterization of crystalline silver nanoparticles from Bacillus cereus isolate," Colloids and Surfaces B: Biointerfaces, vol. 74, no. 1, pp. 191-195, 2009. 

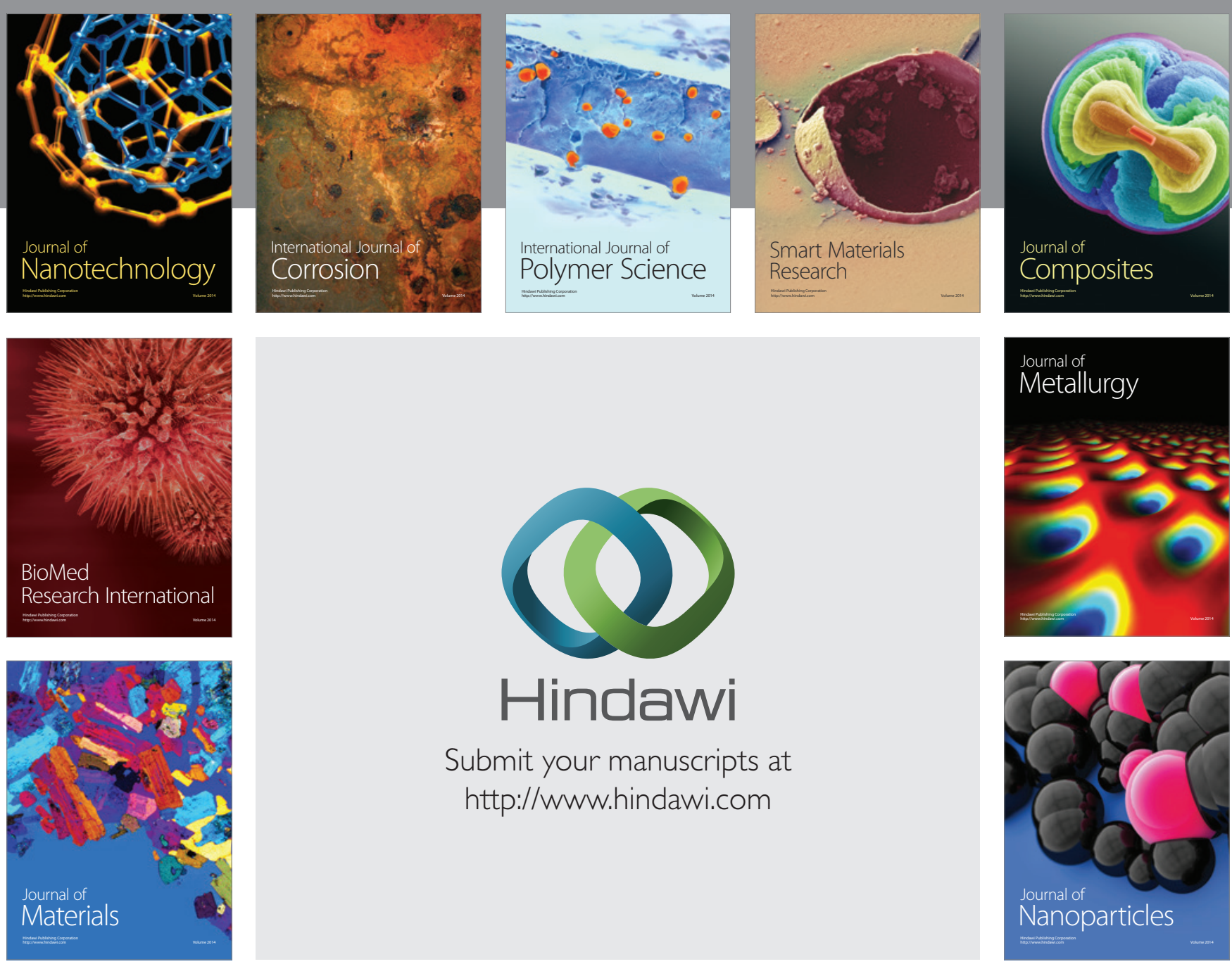

Submit your manuscripts at http://www.hindawi.com
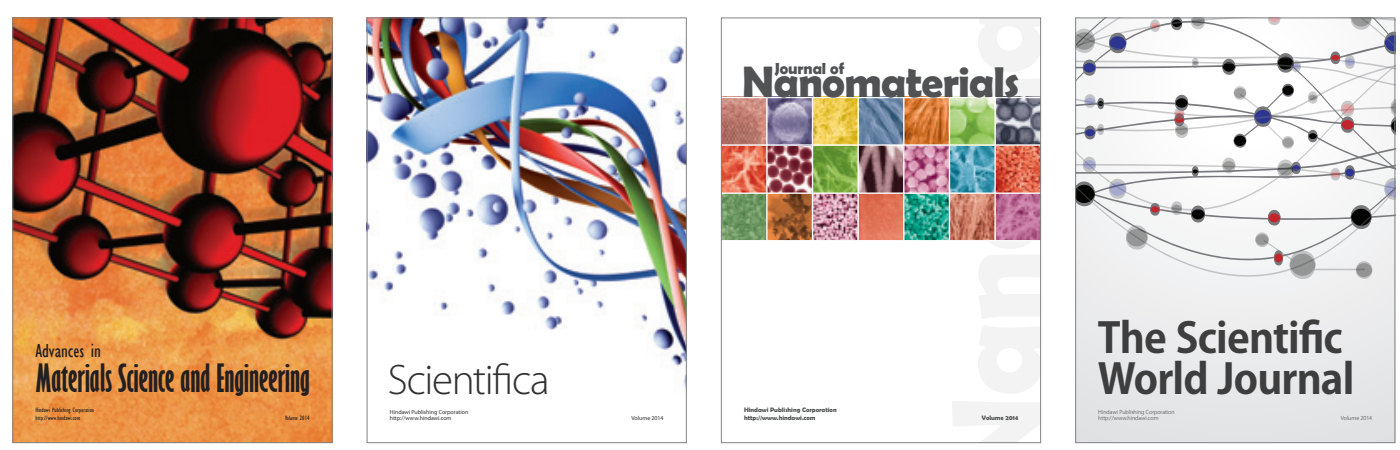

\section{The Scientific World Journal}
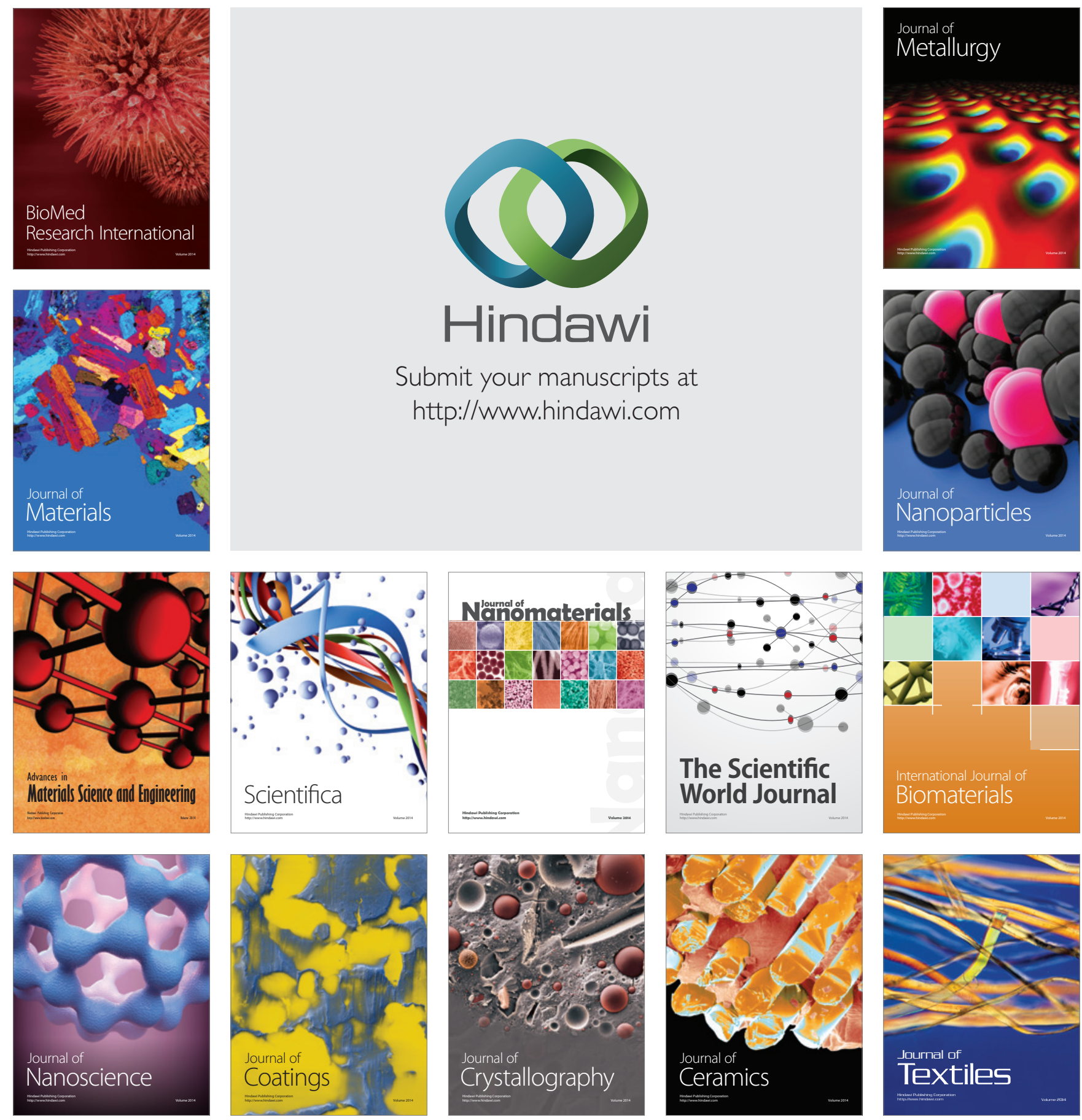